\title{
ヨーロッパの言語療法士 一その社会的位置づけ一
}

\section{倉内 紀子 白坂 康俊}

\section{Systems for Speech Therapy in European Countries}

-With reference to the status and function of speech therapists in their societies-

Noriko Kurauchi and Yasutoshi Shirasaka

\section{I 、はじめに}

昨年, 欧米の言語療法および言語療法士の社会的位 置づけについて調查する機会を得た。

欧米の言語療法に関してこれまでわれわれが知って いたことは, 単に, 免許の性格や療法士の数, 養成制 度の年限などを項目別にアンケート調査した程度のも のだったように思う。

しかし, 日本と欧米諸国では, 法律体系や医療制度 さらに教育制度などがそれぞれ異なっている。言語療 法士の資格制度も，各国でこうしたさまざまな社会背 景のもとに制定され運用されている。

資格制度の内容をただ項目的に調査するのでなく， できるだけその背景にまでたちいって，異なる体制の 中での長所・短所を比較したいというのが，調査に際 しての基本的な考えであった。

また，日本の医療に関する法律は，後に述べるよう に，業務範囲，指示系統，責任の分担などを厳格に規 定する業務制限法的性格をもっている，しかし，欧米 の医療の体制や制度は，もう少しゅるやかであると聞 いていた。それでは，いったいどういう医療体制の中 で言語療法士の資格制度が規定され運用されているの か，できるだけ各々の国の社会的背景を掘り下げてと 考えるように到った一番の動機はそのことであった。

このような観点にたって調査した欧米の言語療法の うち, イギリス, デンマーク, スウェーデン, オラン
ダについて報告する。

なお，言語障害の評価や訓練（言語療法）を担当す る専門職は, わが国では一般に言語療法士 (ST) とよ ばれているが，欧米ではこの名称は国によって異なっ ている，各国の個々の名称についてはそのつど触れる が，本文中の記載は，とくに不都合がない限り言語療 法士あるいはST を用いる。

\section{II. 日本の言語療法士}

ヨーロッパの言語療法について報告する前に，日本 の言語療法ならびにそれを担当する専門職の現状につ いてまとめてみる.

日本で言語療法の対象とされる障害は，(1)失語症お よび言語に関する高次神経機能の障害, (2)運動障害性 構音障害, (3)音声障害, (4)脳性麻痺の言語障害, (5)口 蓋裂言語, (6)言語発達遅滞, (7)機能的構音障害, 8)吃 音, (9)聴覚障害の 9 種類であり,さらに平衡機能障害 を含めるかについて議論がなされている。なお，聴覚 障害は言語障害の 1 つとして扱うのが一般的である.

言語療法を必要とする障害者の総数は約 90 万人で, 日本の人口 1 億 2000 万人の $0.75 \%$ にあっている.

これらの障害者に対して訓練を行う施設は，日本で は, 聾学校や言語障害学級などの教育機関, 通園施設 やリハビリテーションセンターなどの福祉機関, リハ ビリテーション専門病院や大学病院などの医療機関の 3 つに大別される. 
言語障害者に対する訓練・指導の歴史は, 龍学校, 養護学校など教育の分野が先鞭をつけてきた。日本で 医療の分野にリハビリテーションという領域が誕生し てから，ようやく 30 年になるにすぎない.

しかし, 言語障害の改善には, 口蓋裂の手術, 脳血 管障害の医学的管理など原因疾患に対するケアーが大 きな影響をおよぼす。また，構音器官の動きなどに関 する医学的な情報が効果的な訓練プログラムの立案に 不可欠である。しかも, 近年, 言語障害児の早期発見・ 早期療育の有効性や, 脳卒中後のベッドサイドからの 訓練開始の必要性が明らかにされてきた。このような 対応は医療機関でなければできにくく, 実際, ST が医 師や看護婦，PT，OTなどのスタッフと連携して訓 練・指導にあたることで著しい成果をあげている機関 も多い.

こうした状況を背景にして，日本では，歴史が浅い にもかかわらず，医療における言語療法の領域が著し く発展してきた。そしてそれが，医療で治療・訓練を 受ける患者の増加だけでなく, 言語療法の技術や学問 的な発展を促してきたのである。

しかしながら，このように医療における必要性が認 められてきたにもかかわらず，医療および福祉機関て 言語療法を担当する専門職の総数は全国でおよそ 1,000 人にすぎない.この数は, 医療・福祉機関で必要 と推定される言語療法士 5,700 人の $1 / 5$ に満たず，そ のうえ，この 1,000 人のうち，半数以上は専門教育を 受けていないという状況である.

一方の教育機関でも，数の面では言語障害をもつ児 童生徒に何とか対応できているものの; 専門教育を受 けている者が指導にあたっているとは限らず，また， たとえ専門教育を受けていてもその内容が言語障害に 対応するのに必要な医学的な知識を欠いているため, 必ずしも満足のいく状態ではない.

このように，日本において言語障害を担当する専門 職が不足し, 質も保証されていないのは, 担当者の資 格認定制度が確立していないためである。

教育の分野でも，言語障害の児童を担当するための 特別な資格はない.一般教員の免許を所持していれば, 専門知識がなくても言語障害児を担当することができ る.

ところが，医療に関してはさらに深刻で，言語障害 の担当者を規定する資格や免許の制度は全く存在して いない.したがって，医療分野で現に言語療法を担当 している者は, 法解釈上は無資格であり, 違法である ことになる．取締りの対象になるということは現実に はないが，その身分および業務は非常に不安な状況に
置かれている。

さらに, 言語療法の保険点数が 1 回 100 点と非常に 低いため, 一般私立病院では採算が全くとれないので 言語療法を提供できず, 専門職を置くことができない. 公立病院でも正式に職種として認められず, 定数設置 が困難である。

また，資格制度がないために養成制度が確立してお らず, 現在の少ない定数を満たすだけの養成校もない. その結果, 残りは専門教育を受けていない者で埋めざ るをえず, 結果的に, 言語療法を誰がやってもよい状 況にある。

すなわち，日本では，言語療法を担当する専門職が 極端に不足しており，また，その専門職は必要な専門 教育を受けているとは限らない. 言語障害者がいつで もどこででも適切な言語療法を受けられる状態から程 遠い現実にある。

\section{III. ヨーロッパの言語療法士}

\section{1.イギリス}

イギリスでは，言語療法士は Speech Therapist と よばれている，その数は約 4,000 人で，日本の半分の 人口のところに 4 倍の ST がいることになる.

一般に「言語療法は医療である」と考えられており， この基本的な考えに基づき $80 \%$ 以上の ST がヘルス サービス，すなわち医療の分野(日本の厚生省に相当) に属している。それでいて実際に ST が働いている場 所は, 医療機関だけでなく, 学校, 老人ホーム, 自宅 訪問まで, 医療・福祉・教育のすべての領域にわたつ ている. 行政上 1 つの領域に属しながら他の領域でも 働けるというのは, 日本の枠組から考えると理解し難 いが，これを可能にしているのはディストリクト・ス ピーチセラピストという制度があるからである.

イギリスにはディストリクトとよばれる行政区があ り，ほとんどの ST がこのディストリクトに属してい る. 地方公務員のようなものだが，日本であれば，地 方公務員であっても実質的には地方自治体が設置した 病院や学校など実際に働いている職場に所属し, 上司 はその機関の長となる.しかしイギリスの場合には， ディストリクト・スピーチセラピストという 1 つの独 立した機構があって, ST は皆そこに属するのである. この機構はヘルスサービス, すなわち医療に位置づけ られており，ST はそこから病院や学校などあちこち の機関に派遣されて仕事をする(図 1). 採用も個々の 病院や学校によってではなくディストリクトによって 行われ, 給与もディストリクトから支給される.

イギリスは約 200 のディストリクトに分かれてい 
る.1つのディストリクトの例を図 2 に示した。

チーフも ST 自身で, どこにどのように ST を配置 し, どういう仕事をさせるか, 給与はどうするかなど 管理的な仕事が中心の, いわば総括責任者でありチー フIとよばれている.

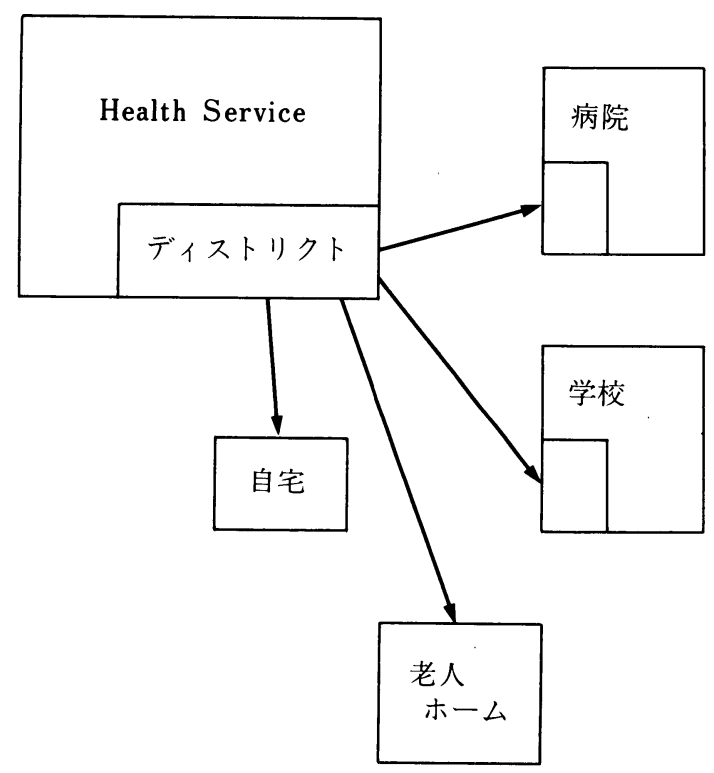

図 1 ディストリクトスピーチセラピスト
ロンドンにある人口約 45 万人という比較的規模が 大きいこの地区の場合, チーフ I のもとに 2 名のチー フIIがいる，各々病院サービス部門（成人が主体）と 地域サービス部門（小児が主体）の統括が仕事で，チ ーフ I と同様, 臨床業務は少ない.コーディネーター としての役割が主体になる。

病院サービス部門のチーフIIのもとには 7 名のチー フIIIが，地域サービス部門のチーフIIのもとには 5 名 のチーフIIIがいる，チーフIII以下が実質的な実働メン バーである，病院サービス部門では，ディストリクト 内を 3 つの小地域に分け 3 名のチーフIIIが分担するほ か, 老人, 音声障害, 精神薄弱者のサービスを専門に 担当するチーフIII，小児まで含めた言語センター担当 のチーフIIIがいる，一方，地域サービス部門の方は， 地域でのサービスを聴覚障害児, 言語障害児, 保健所, 発達遅滞児, 精神薄弱者の 5 つに分け，5名のチーフ IIIが担当している.

そして,以上 12 名のチーフIIIのもとにそれぞれ 5 名 前後の ST がいて, 各々が病院や学校, 保健所, 老人木 ームなどで働いているのである.

こういった分割の仕方は，ディストリクトによって 人口, 病院の数などに合わせて変わっていくが, 全体 的なピラミッド型の構造は同じである.

一人の ST が, 週の前半は病院, 後半は学校で働くと いうこともあるし，1日の内でも午前中は学校で午後

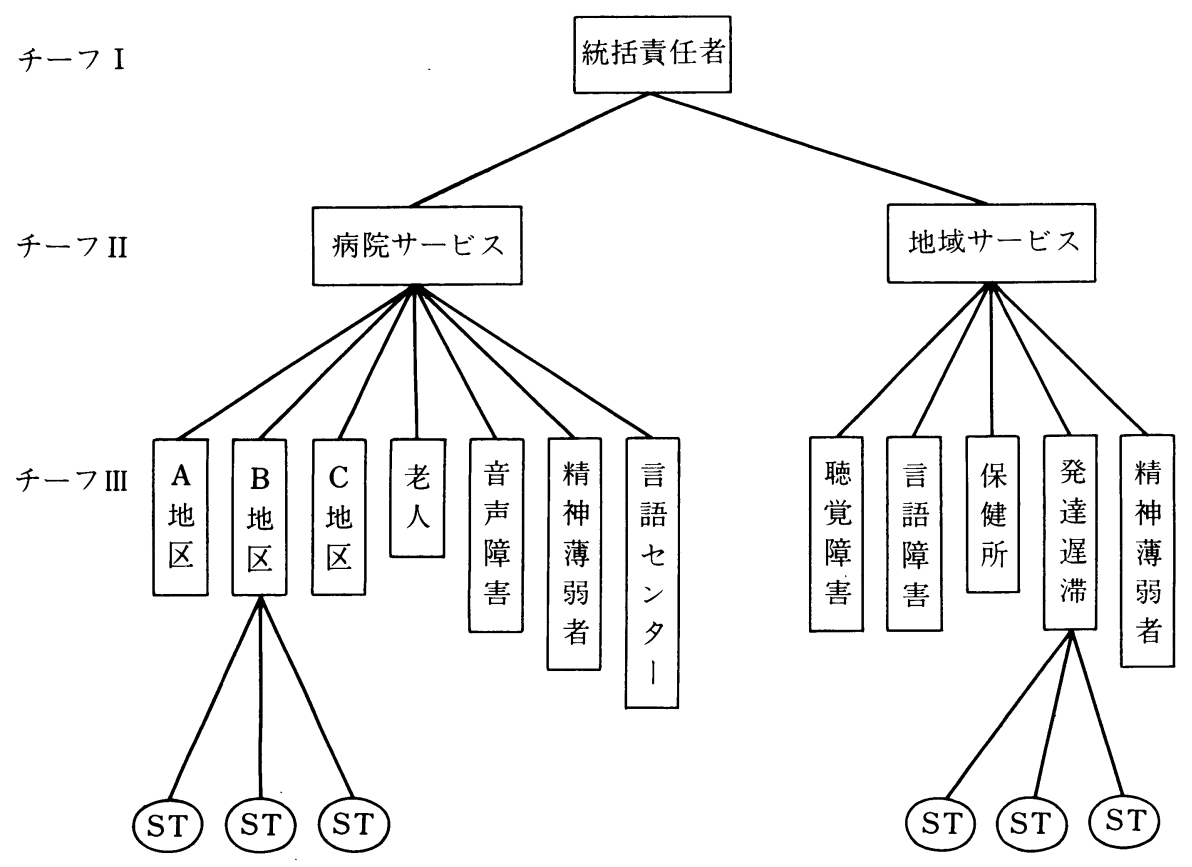

図 2 ディストリクトの組織 
は病院というょうな場合もある，それが，日本でいう 非常勤ではなく，所属がそもそもディストリクトで, そこから必要に応じて派遣されるのである.

障害者の数や言語療法の需要の変化, さらには ST 数の増減などに対して臨機応変に対応できるのは,こ のシステムの長所の 1 つであろう. ST の配置を含む サービスの体制の決定権がチーフ I にあるからであ る.

このように，ST のサービス体制がかなり独自性を もって,しかも行政上のシステムとして実現されてい る背景には，The College of Speech Therapists とい う言語療法士の協会の役割が大きい.

ST の養成課程は 4 年で, 全国に 16 の養成校がある が, 協会の学術委員会 (academic board) がこれら養 成機関のカリキュラムを 5 年毎に審査するというチェ ック機関になっている.さらに, 卒業生に対して ST の 認定書（国家資格）を発行する審査機関は，この協会 なのである，いずれも協会が国，厚生省の委託を受け て行っている.

このように, 協会は 1950 年台の設立当初から, 資格 養成制度や業務内容の規定, サービス体制の決定など についても実質的な役割を果たしてきている。

イギリスの制度は，ST 自身に独自の決定権がある こと, 医療や教育など領域によってサービス内容に質 的な差ができにくいこと, 行政上の機構であるため地 域差の問題も解決しやすいことなどを長所としてあげ ることができる.

逆に短所として, 医師や教師など各機関内の他職種 とのつながりが希薄になる可能性があること, 人件費 がかかり財政上の問題が出ていることなどを指摘でき る. 実際，この財政的な問題は深刻で，このシステム が数年後には維持できなくなるという見方もある.

\section{2. デンーク}

イギリスではすべての ST が医療に属し, 独自性の ある行政的なシステムが実現されていたが，デンマー クのシステムもこれに似ている.

デンマークでは, すべての ST が教育 (日本の文部省 に相当)に属している，すなわち，「言語療法は教育で ある」というのが基本的な考えである.この「教育」 の概念が日本とは大きく異なるものであることは後に 述べるが, ともかく,すべての ST が行政上は教育の分 野に属しながら, 実際には学校だけでなく医療機関で も福祉機関でも働けるということになっているのであ る.

イギリスではほとんどすべての ST がディストリク トという 1 つ機構に属していたが, デンマークでは,
14 に区分されたカウンティ（日本の県に相当）に属す るST と, さらにその下の単位であり $275 に$ 細分化さ れたコミュニティ（日本の市町村に相当）に属する ST に二分される。

カウンティに属しているST は, カウンティが管轄 している機関, 主として成人を対象とする病院で働き, コミュニティに属しているSTは, コミュニティが管 轄している機関, 主として学校で働く。この結果, 成 人と小児というふうに対象年齢によって ST が分かれ ることとなった。

成人を対象としている者が約 300 名, 小児（ $0 \sim 16$ 歳) を扱っている者が約 700 名で, 人口 500 万人のこ の国におよそ 1,000 名のST がいる.

カウンティのシステムを図 3 に示した. カウンティ に属して成人を対象とするSTは，すべて， Speech Institute とょばれる機構に所属している。この Speech Institute はカウンティの教育部門の中に位置 づけられており, 病院で働くSTも行政上は教育に属 することになる.ST が個々の病院に属さないのはイ ギリスと同様である.

Speech Institute にはカウンティの大きさによって も違うが 20 名前後の ST がいて,ここから病院や老人 ホームなどに派遣されるのである，逆に，病院から患 者がくることもあり Speech Institute でも臨床が行わ

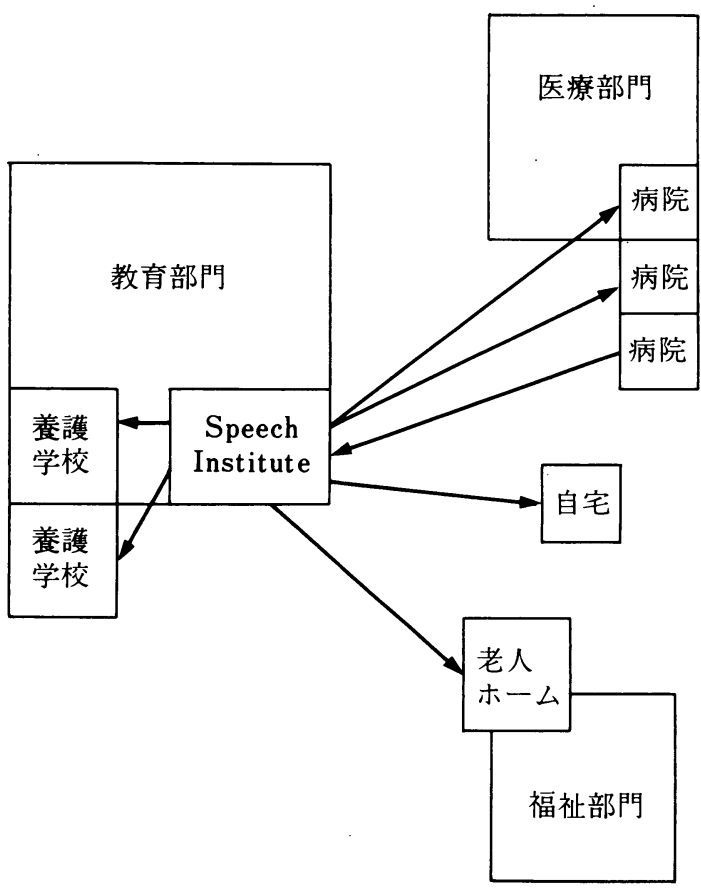

図 3 カウンティのシステム 
れている。

「患者がいればどこででもできる」というデンマー ク言語療法士協会の会長のことばどおり, ST は, この Institute から患者がいる所にどこへでも出かけて行 くことができる.

なお, 学校のうち Special School は例外的にカウン ティに属し, 養護学校へも必要に応じて ST が派遣さ れる.

そして，イギリスの場合と同様，たとえ病院で働い ていようとも彼らの長は Institute のチーフ (ST) であ り, 給与もカウンティから支給される.

次にコミュニティのシステムを図 4 に示した。コミ ユニティに属して小児を対象とするSTは, コミュニ ティの教育部門の中に位置づけられた School Psychology Service に属している. ST は，1つの学校を 拠点に周辺の 2,3 力所の普通学校と 3,4 力所の幼 稚園を担当し, 0 歳から 16 歳までの聴覚言語障害児に 対するサービスを行う。

このように,成人を担当する ST も，小児を担当する ST も，基本的に教育の分野に属するのである.

ところで，デンマークの「教育」の概念は日本とは かなり異なるものである。デンマークでは，いわゆる 学齢児に対する学校教育だけでなく, 成人の障害者に

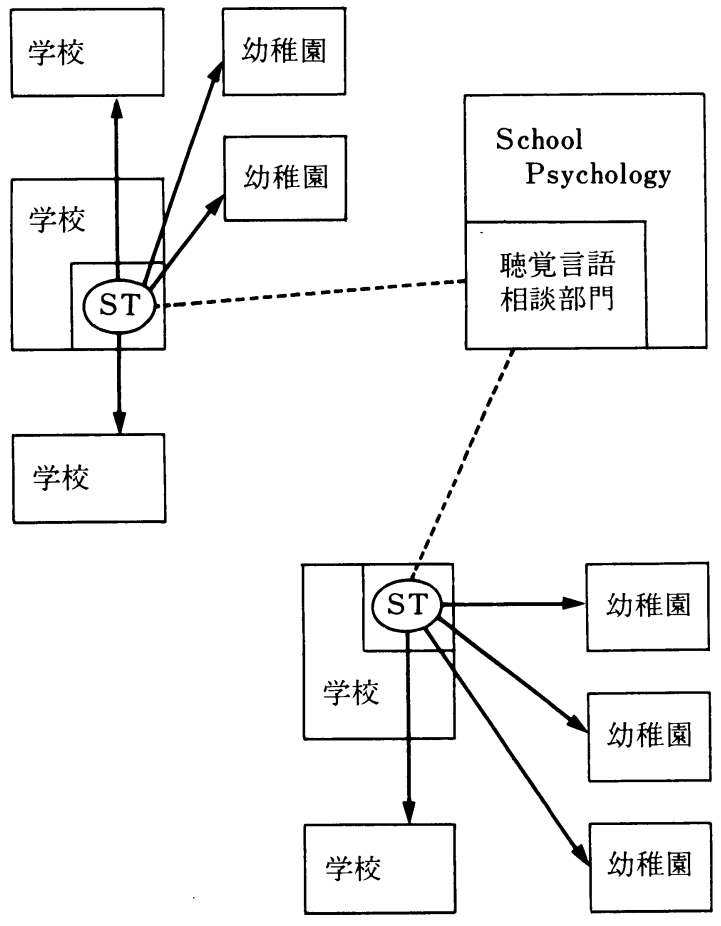

図 4 コミュニティのシステム
対するサービスも「教育」であるし，さらには一般成 人に対する短期コースも「教育」なのである．教育の 分野に属しながら ST が病院で成人の失語症も扱える のは，それが「教育」の範疇に入るからである。

そして，このように，成人に対する生涯教育も含ん だ広い意味での「教育」という概念の中に ST の業務が 位置づけられていることが，資格制度にも反映されて いる.

デンマークの ST は Logopæd とよばれているが, その資格養成制度は，普通教員の資格と 2 年以上の経 験の上に ST としての 1 年半の専門教育を付加したも のである.したがって,すべての ST が基礎資格として 教員免許をもっている.

カウンティに属する ST はこの Logopæd の資格が 必須であるが，コミュニティに属し小児を対象とする 場合, 教員の資格があれば必ずしも Logopæd の資格 は必要ない.ただし, 実際には Logopædの資格をもつ 人がほとんどである。

なお, 1982 年にコペンハーゲン大学に ST の養成課 程が設置された。現在 (1988 年 6 月) のところ卒業生 はまだでていないが, 近い将来, 教員の資格をもたな い新しいST が誕生する。彼らは, 教員の資格がないた め, 成人を対象とするST としてカウンティで働くこ とになる。

コペンハーゲン大学の主任教官が, このコースの設 置について,「教員 $+\alpha$ ではなく, コミュニケーション 障害そのものに焦点をあてた教育が必要ということで 設立された。理論的で科学的なカリキュラムが特徵で ある」と語っていたのが印象的であった。

デンマークのシステムは, すべての ST が行政上同 じ領域に属し, しかも独自の機構をもつことによって 他の領域でも働けるという, イギリスと同様の特徵を もつ. その領域が医療ではなく教育である点, さらに 基本的に成人と子供の 2 つに分かれている点が異な る.

なお，デンマークの言語療法士協会も，1920年台設 立という歴史と伝統を有し, 養成校の開設やその内容 に関して強い発言権をもっている.

\section{3.スウェーデン}

スウェーデンの制度の特徵は, ST が医療と教育と いう領域に二分され，その資格制度も異なる点である。 イギリスやデンマークのように, ST が基本的に同じ 領域に属し, その上で病院ででも学校ででも働けると いうことは，スウェーデンではない.

スウェーデンの ST は, $0 \sim 7$ 歳と 19 歳以上を対象 に医療分野で働く Logoped と, 7 19歳を対象に教 
育分野で働く Talpedagog の 2 職種に分かれている. 人口およそ 800 万人に対して, 約 600 名の Logoped と，それよりはるかに多い Talpedagog が存在する. そして, Logoped も Talpedagog も, カウンティのよ うな行政区にではなく，それぞれ医療機関あるいは教 育機関に所属している.

たとえば,ストックホルム近郊の人口約 40 万人の地 域では, 1 大学病院が, その地区の $0 \sim 7$ 歳および 19 歳以上の全言語障害者をカバーしている。

その病院の言語部門は, 医師 2 名 (内 1 名は部長), 看護婦 1 名, ST つまり Logoped 14 名(内 1 名は主任) という構成である.すなわち, ST のチーフはあくまで その病院のその部門の主任であり部長である。これは, イギリスやデンマークとは異なり，どちらかというと 日本的である。

また, 前述のように, Logoped と Talpedagogは, その領域, 職域, 対象年齢だけでなく資格養成制度も 異なっている.

病院 ST である Logoped は, 大学病院と隣接した養 成課程で 3 年間の専門教育を受ける. それに対して, 学校 ST である Talpedagog は， 3 年以上の普通教員 としての経験をへたあと 1 年の専門教育を受ける.

このように複数の資格制度があることから, 医療や 教育など領域によってサービス内容に質的な差ができ ることが懸念されるが, それを, 逆に, 対象年齢とい うきちんとした役割分担によってカバーしているとも いえる.

\section{4. オランタ}

人口 1,400 万人のオランダには約 4,000 名の ST が いる. そして, その半数以上が教育の分野で働いてい る.残りが医療分野で, そのうち開業している ST の割 合は，今回取り上げた 4 力国の中でいちばん多い.

ST は Logopedist とよばれ資格養成制度は 1 種類 である。

養成校は 4 年間の Higher School とよばれる学校 で, PT や OT, 看護婦, 保母, 小学校の教員などもこ こで養成される. Higher School は日本でいう文部省 に属するが, ST の資格は厚生省によって交付される. そして, 学校で働くSTもこれが必要である.イギリス と同様, ST が医療であると考えられていることが伺 える。

また, オランダでは, 保険制度が他の 3 カ国とは異 なっている，スウェーデンやデンマークそしてイギリ スは, 基本的に言語療法は無料である. 現在のところ オランダでも国民保険と民間保険という 2 種類の保険 のどちらかでカバーされているが，その制度は必ずし
も正常に機能しているとはいえず，言語療法を保険の 適応からはずすとか, ST のポストや養成校の削減な ど, 国全体の経済的な情勢とからんだ深刻な問題が STに提示されている.

なお，開業して国民保険の患者を扱うためには，訓 練室の面積, 待合室や患者専用のトイレの設置, 検査 訓練用機器, 訓練の頻度などの最低基準が厳密に規定 されており,これを満たすことが義務づけられている. 民間保険の場合にはそのような基準はないが, 医師で なければ保険会社に指示を書けず，患者を紹介してく れるような医師の存在が不可欠であるということにな る.

このように, 保険制度などの外的な制限が厳しくな ってくると, 医師との関係の問題がでてくる.このあ たりの事情や行革の動きなど，ここでも日本と似た印 象を受けた。

\section{IV. 考 察}

以上述べてきたように，国によって言語療法の領域 や基本的なサービスの体制, 資格養成制度の内容は異 なっていた。

しかし, 共通していえるのは, どの国にも言語障害 を担当する専門職の資格養成制度があり, その国の実 情に合わせたサービスの体制ができているということ である。すなわち, ST は, 独自のしかも社会的に位置 づけられた領域をもっている。 そして, 少なくとも患 者がサービスを受けられない状態, 受けられない場所 がないということである.

また，医療とか教育とか領域の話をするとき，日本 の場合には，その施設が医療に属するか教育に属する かが問題になる。しかし，ここでみたヨーロッパの国 では, 領域というのはサービスの内容が医療的である か教育的であるかという概念であり，施設の性格によ る制限は少ない。

行政上は医療に属しながら教育機関でも働けると か, 基本的に教育に属しながら病院でも自宅訪問とい うかたちでも仕事ができるというのは, 医療制度や領 域という概念の枠組が日本に比べてかなりゆるやかで あることが影響していると考えられる。

ところで, 日本の言語療法の学問的な水準や技術的 な面に関しては, 音声障害などいくつかの障害を除く と, おそらく世界的にみてもトップレベルであろう。 実際に臨床場面を見学したり, 各国の言語療法士とデ イスカッションをしてきて, そういう印象を強くもつ た.

しかし, 日本の ST には社会的に位置づけられた領 
域がない. 専門職の数も圧倒的に不足しており, 質的 なばらつきも大きい。日本では, 言語障害者がいつで もどこででもサービスを受けられるという状態からは 程遠い.

このような現状を打開する方策として, 25 年以上も 前から，医療における言語療法士の資格制度制定の運 動が，当事者はもとより関連する医学会などによって なされてきた。

そして，この間何度かは実現直前まで話が進みなが ら, 現在に到ってもまだ制定されていないのは, 主に 当事者の一部すなわち現に言語療法を担当している 人々の間に反対の意見が存在するからである. 反対を 唱える人は，必ずしも資格制度制定自体を否定してい るわけではなく, 提唱されている資格制度の内容につ いて不服とする人がほとんどである。

反対を唱えている人の意見には，教育年限が不足で あるという養成制度に関すること, 医師から独立した 資格にしてほしいという医師との関係に関すること, 医療だけの資格でなく教育も含めた資格にしてほしい という領域の問題に関することなどがある.

これらの意見の中にはもっともな主張もあり，この ような資格制度が実現できるのであれば，言語療法士 の専門性の向上や障害者に対するサービス体制にとつ て望ましいことはいうまでもない.しかし，現実には， 現在の日本の医療制度や社会体制の中でこれらの意見 を盛り込んだ資格制度を制定するのは不可能に近い.

そこで，以上のようなことが認められなければ資格 制度制定は見送るべきであるといった反対意見と，現 実的な選択をし，まず現在の医療体制の中で実現不可 能な資格制度を制定しようとする意見とが，当事者の 間で対立しているのである。

それでは，これらの主張の実現が不可能なのはなぜ であろうか.そのことを理解するためには，日本の医 療の特殊性すなわち日本の医療制度の特質について考 察する必要がある。

日本の医療制度は法的な規制が非常に厳しい，それ は，医療は他の業務に比べて，サービスを受けた患者 の側がその行為の適否を判断することが難しく，しか も誤った行為がなされた時の患者の不利益が深刻であ るという考えに基づいている。そこで，日本の医療に 関する法律は，業務範囲を厳格に規定する業務制限法 的性格をもっている.

資格や免許制度というのは, ある業務や行為を行う ために必要な知識や技術をもつ者のみにそれを行うこ とを許可するもので，同時に，必要な知識，技術を獲 得するための養成や教育の最低基準も規定される。そ
れによって，その業務や行為の質が保証される。

現在日本で医療職として規定されているのは, 医師, 看護婦, 薬剂師, PT, OT, X 線技師, 検査技師など で，これらの専門職が現行の業務制限法的な医療制度 の中に位置づけられている.

業務の範囲が厳しく決められているということは, 裏返せば，厳密な責任論が伴うということで，業務の 指示系統, 責任の分担などの関係が非常に厳密に決め られているということである。したがって，他の医療 職が医師の指示で業務を行っているのに, 共同で業務 にあたる言語療法の担当者だけが医師の指示を受けず に，独立の資格でそこに参加するというような体制を つくることは, 現在の医療の体系を根本的に改革しな い限り困難である。

一方, 教育の免許は医療に比べて非常にゆるやかな 規定であり，他の職種との責任体系などはほとんど規 定されていない，さらに，医療や教育という領域が欧 米に比べてはっきりと分かれており, 各々に属する機 関や専門職を管轄する省庁も違う。このように，全く 性格の異なる分野の資格制度を 1 つの法律で規定する ことは，現在の日本では非常に困難である，したがっ て, 教育を含めた資格制度というのはさらに実現不可 能なのである。

今の日本の言語療法士にとって重要なことは, 資格 制度ができないまま放置するのでなく, 現在の日本の 社会の仕組みを考慮した上で, まず障害者がサービス を受けられる状況をつくること，すなわちサービスが 受けられない状態や受けられない場所をなくすことで ある。そのためには，日本の実情に合った資格養成制 度をつくらねばならない。そしてその前提は, 言語療 法が社会の中に位置づけられるということである.

何もない所につくるのではないから，既存の枠組に ある程度添うことはやむを得ない，そこに，枠組が異 なるものを，しかも，ある特定の部分だけをもちこむ ことはできない，まず，法律体系，医療・保険制度， 教育制度など，日本の制度を十分に考慮した資格養成 制度およびサービスのシステムをつくることが先決で ある。

将来的には，その上で，医療制度など制度そのもの に対する検討を加えていくような視点が必要であると 考えている．業務制限法的な考え方にしても，時代の 変化を考えると時代遅れの感がある. 国民の意識は大 きく変化してきているし，不正な医療に対する批判の 目ももっている，一方，リハビリテーションの分野で は，それに関与する専門職各々の独自な判断が重要で あり，チームアプローチが原則ということは常識にな 
ってきている。そういう意味で, リハビリテーション の分野は医療制度それ自体を改革していく突破口にも 成り得る分野である。

しかしそうした全体の制度の問題に関与していくの は, 言語療法という領域がきちんと社会的に位置づけ られたあとの問題である。そのためにも，まず資格制 度がいるのである。

養成制度の年限や, 言語療法は医療か教育かといっ た議論がもう 25 年以上も繰り返されている.その結果 未だに資格制度がなく, 言語療法自体も, それを担当 する職種も, 社会的に認知されているとはいい難い. これは, 言語療法の領域の発展にとって, そして何よ りもサービスを受ける側の障害者にとって, 大変に残 念な現状である。

この状況を打開するための言語療法士自身の役割と 責任は大きい.

ヨーロッパの言語療法に関するこのささやかな報告 が, 日本の現状を見直す 1 つきっかけになれば幸い である.

\section{V. まとめ}

イギリス, デンマーク, スウェーデン, オランダの
言語療法および言語療法士の社会的位置づけについて 調查した結果を報告した。

国によって言語療法の領域や基本的なサービスの体 制, 資格養成制度の内容は異なっていたが，どの国に も言語障害者を担当する専門職の資格養成制度があ り，その国の実情に合わせたサービスの体制ができて いた。また，医療制度そのものや，医療・教育という 領域の概念が日本に比べてゆるやかであり, それが資 格制度の運用に反映されていた。

日本には言語療法士の資格制度はなく, 言語障害者 に対するサービスの体制も非常に不十分である。この 状況を打開するためには, 法律体系, 医療・保険制度, 教育制度など, 日本の制度を十分に考慮した資格養成 制度およびサービスのシステムをつくることが先決で あると考えられた。

今回の調査に関する準備とまとめにはわれわれが共同であた つたが, 各国の現状に関する実際の調查は, 清水基金の助成を受 けて，倉内が実施した。このような機会を与えてくださった清水 基金に謝意を表する。 